\title{
TIPOLOGIJA POTROŠAČA S OBZIROM NA NJIHOVU SKLONOST OSTAVLJANJU NAPOJNICE U RESTORANIMA ${ }^{1}$
}

\section{TYPOLOGY OF CONSUMERS BASED ON THEIR TIPPING BEHAVIOR TENDENCY IN A RESTAURANT SETTING}

SAŽETAK: Pored cijene koju je potrošač dužan platiti za primljenu uslugu, davanje napojnice za istu tu uslugu predstavlja njegovo svjesno i namjerno izlaganje dodatnom novčanom trošku. S obzirom na to da bi potrošač mogao izbjeći ovaj trošak, ovim se radom nastoji odgovoriti na pitanje zašto potrošači ipak ostavljaju napojnice za primljenu uslugu u restoranima te postoje li razlike među potrošačima s obzirom na ovaj oblik njihova potrošačkog ponašanja. U tu su svrhu postavljena dva cilja rada, pri čemu je prvi cilj bio utvrditi strukture motivacijskih čimbenika zbog kojih potrošači ostavljaju napojnicu za primljenu uslugu u restoranima, dok je drugi cilj bio utvrditi mogu li se na temelju različitih struktura motivacijskih čimbenika potrošači grupirati u zasebne tržišne segmente. Empirijsko istraživanje provedeno je metodom ankete na prigodnom uzorku koji je činilo 106 ispitanika. Podaci su prikupljeni pomoću anketnog upitnika, koji je bio dostupan u elektroničkom obliku. Rezultati istraživanja pokazali su da postoje različite strukture motivacijskih čimbenika kada je u pitanju ostavljanje napojnica u restoranima, kao i to da se na temelju tih razlika potrošači mogu grupirati u zasebne tržišne segmente, ovisno o tome koja kombinacija motivacijskih čimbenika dominantno karakterizira promatrani oblik potrošačkog ponašanja. Ovo se ujedno može smatrati i osnovnim teorijskim doprinosom rada. Praktični doprinos rada ogleda se u tome što se marketinškim stručnjacima u području usluga pružaju smjernice koje dimenzije kvalitete usluge poboljšati, što bi se moglo odraziti na sklonost gostiju ostavljanju napojnice, ali i na zadovoljstvo zaposlenika.

Prof. dr. sc. Sunčana Piri Rajh, redovita profesorica, Ekonomski fakultet Sveučilišta u Zagrebu, Katedra za marketing, Trg J. F. Kennedyja 6, 10000 Zagreb, e-adresa: spiri@net.efzg.hr

** Ivona Koledić, mag. oec., asistentica u marketingu, CMC televizija, Makarska 3, 10040 Zagreb, e-adresa: ivona.koledic@gmail.com

1 U radu su korišteni podaci prikupljeni za potrebe izrade diplomskog rada Ivone Koledić, mag. oec., koji je napisan pod mentorstvom prof. dr. sc. Sunčane Piri Rajh i obranjen na Ekonomskom fakultetu Sveučilišta u Zagrebu. 
KLJUČNE RIJEČI: ostavljanje dodatnog novčanog iznosa (napojnice), motivacijski čimbenici ostavljanja napojnice u restoranima, tipologija potrošača, segmentacija tržišta

\begin{abstract}
Besides the price that the consumer is obliged to pay for the service received, a tipping behavior represents his conscious and intentional exposure to an additional monetary cost. By taking into account that the consumer could avoid this type of cost, the purpose of the paper is to provide the answer, why restaurant customers leave tips for the service received, and whether there are differences among customers concerning this type of consumer behavior. Therefore, the two aims of this paper are as follows. The first aim is to determine the structures of motivational factors that characterize restaurant tipping behavior, while the second aim is to determine whether consumers can be grouped into different market segments, regarding the different structures of motivational factors. Empirical research has been conducted on a convenient sample of 106 respondents. Data were collected using an online survey questionnaire. The research results have shown the following. Different structures of motivational factors that affect restaurant customers to engage in tipping behavior can be identified. Also, consumers can be grouped into different market segments, depending on the motivational factor structure that characterizes their tipping behavior. The aforementioned can be considered as the main theoretical contribution of the paper. The practical contribution of the paper refers to the fact that marketers are provided with guidelines regarding the service quality dimensions that need to be improved. This could affect the restaurant guests' tipping tendency, as well as employees' satisfaction.
\end{abstract}

KEYWORDS: consumers' tipping behavior, motivational factors of restaurant consumers' tipping behavior, consumer typology, market segmentation

\title{
1. UVOD
}

Ostavljanje dodatnog novčanog iznosa za pruženu uslugu ili, jednostavno rečeno, ostavljanje napojnice, tema je koja dugi niz godina zaokuplja pozornost znanstvenika iz područja ponašanja potrošača, ekonomije, sociologije i psihologije (Lynn, Zinkhan i Harris 1993). ,Zašto racionalni pojedinac ostavlja napojnice?“ prema Lynnu (2006: 14) predstavlja jedno od osnovnih pitanja na koje brojne teorije i modeli nastoje odgovoriti, odnosno objasniti ovo dobrovoljno potrošačko ponašanje. S obzirom na to da se svjesno i dobrovoljno ostavljanje dodatnog novčanog iznosa za pruženu uslugu ujedno može smatrati i iracionalnim, odnosno nelogičnim ekonomskim ponašanjem potrošača, jer se potrošač tim činom namjerno izlaže dodatnom trošku koji bi mogao izbjeći (Lynn 2006), te s obzirom na to da dosadašnja istraživanja nisu rezultirala jasnim spoznajama o ovom obliku potrošačkog ponašanja, kao i o njegovim uzrocima (Fisher 2009), ovim radom nastoji se odgovoriti na pitanja zašto potrošači ipak ostavljaju napojnice za primljenu uslugu u restoranima te postoje li razlike među potrošačima s obzirom na ovaj oblik njihova potrošačkog ponašanja. U tu su svrhu postavljena dva cilja rada. Prvi cilj je utvrditi strukture motivacijskih čimbenika zbog kojih potrošači ostavljaju napojnicu za primljenu uslugu u restoranima. Drugi cilj je utvrditi mogu li se na temelju različitih struktura motivacijskih čimbenika potrošači grupirati u pojedine tržišne segmente. Odgovori na postavljena pitanja mogu pridonijeti daljnjem razumijevanju ovog oblika potrošačkog ponašanja, kao i teorijskih koncepata povezanih s 
istim, ali i pružiti određenu praktičnu vrijednost marketinškim stručnjacima u poslovnoj praksi u vidu preporuka i smjernica za poboljšavanjem ponude restorana.

Znanstvena literatura bilježi brojna istraživanja o ponašanju potrošača u vidu ostavljanja dodatnog novčanog iznosa za korištenu uslugu u restoranima (npr. Gössling et al. 2021; Lynn 2015; Parrett 2006; Lynn et al. 1993). Pritom brojni autori upućuju i na činjenicu da je ovaj oblik potrošačkog ponašanja kulturološki uvjetovan, odnosno pod utjecajem lokalnih običaja (npr. Liu 2008; Becker, Bradley i Zantow 2012; Casey 2001a). U tom smislu, s jedne strane postoje zemlje u kojima se ovakvo ponašanje potrošača očekuje, dok s druge strane postoje i one zemlje u kojima ovakva praksa nije uobičajena ili čak nije ni prihvatljiva (Hoaas i Bigler 2005; Raspor i Divjak 2017). Nadalje, većina znanstvenih istraživanja o ovom obliku potrošačkog ponašanja provedena je u Sjevernoj Americi, no kada su u pitanju europske zemlje, treba istaknuti da među njima postoje brojne razlike u kontekstu promatranog potrošačkog ponašanja, i to u pogledu učestalosti ostavljanja napojnica te iznosa napojnice u odnosu na plaćeni račun (Gössling et al. 2021).

Budući da je evidentno da postoje razlike među zemljama u stavovima potrošača i njihovoj sklonosti ostavljanju dodatnog novčanog iznosa za pruženu uslugu, ali i s obzirom na to da s vremenom može doći i do promjene u stavovima tako da ova praksa postaje prihvatljiva ondje gdje to dosad nije bila (Casey 2001b), navedeno upućuje na zaključak da ostavljanje napojnice nije univerzalno prihvaćena društvena norma, što uostalom navode i Chang i Chiu (2008), a to predstavlja dodatan argument za provedbu daljnjih i kontinuiranih istraživanja. Isti argument vrijedi i u slučaju Hrvatske, gdje još uvijek ne postoji dovoljno znanstveno utemeljenih spoznaja o ovakvom obliku potrošačkog ponašanja.

Dodatnim argumentom za provedbu daljnjih istraživanja može se smatrati i činjenica da je znanstvena literatura koja opisuje mogućnost segmentacije tržišta na temelju motivacijskih i ostalih čimbenika koji se vežu uz potrošače prilikom ostavljanja napojnice u restoranima oskudna.

U nastavku rada daje se pregled spoznaja o čimbenicima koji motiviraju potrošače na ostavljanje napojnice za pruženu uslugu, kao i mogućnost segmentacije tržišta s obzirom na ovaj oblik potrošačkog ponašanja, a sve to u kontekstu restoranskog okruženja.

Ovaj se rad sastoji od šest cjelina. Nakon uvodnog dijela, u kojemu se opisuje svrha rada, slijedi teorijski okvir, u kojemu se na temelju pregleda dostupnih znanstvenih izvora detaljnije opisuje problematika predmetnog potrošačkog ponašanja, i to kroz odabrane motivacijske čimbenike ostavljanja napojnice u restoranima, te kroz mogućnost segmentacije tržišta s obzirom na sklonost pojedinaca za uključivanjem u ovaj oblik potrošačkog ponašanja. Treći dio rada posvećen je opisu metodologije istraživanja. Obilježja izdvojenih segmenata potrošača koji se razlikuju u svojoj sklonosti ostavljanju napojnice u restoranima opisana su u četvrtoj cjelini, koja se odnosi na prikaz rezultata provedenog empirijskog istraživanja. U okviru rasprave, koja predstavlja peti dio rada, dodatno se diskutiraju nalazi provedenog istraživanja. Rad završava šestom cjelinom, zaključkom, u okviru kojega se sažima prethodno analizirano te se iznose ograničenja istraživanja i preporuke za buduća istraživanja. Nakon zaključnih razmatranja, slijedi popis korištenih izvora. 


\section{TEORIJSKI OKVIR}

\section{1. Čimbenici koji utječu na sklonost potrošača dobrovoljnom ostavljanju dodatnog novčanog iznosa (napojnice) u kontekstu restorana}

Znanstvena literatura promatranog područja opisuje brojna istraživanja koja su utvrđivala kako pojedini čimbenici utječu na sklonost potrošača da dobrovoljno plati i dodatni novčani iznos uz već definiranu cijenu koju je dužan platiti za primljenu uslugu u restoranu. Neki od čimbenika, koji se ujedno i najčešće pojavljuju u dosadašnjim istraživačkim radovima, opisani su u nastavku. Riječ je o kvaliteti hrane i usluge, ljubaznosti i profesionalnosti poslužitelja, društvenoj normi, obilježjima restorana, načinu plaćanja i visini napojnice te raspoloženju posjetitelja restorana.

Kvaliteta hrane i usluge pokazala se jednim od najvažnijih čimbenika ostavljanja dodatnog novčanog iznosa za pruženu uslugu (Yesiltas et al. 2014). Štoviše, riječ je o izrazito važnoj odrednici promatranog potrošačkog ponašanja koja je pritom i kulturološki uvjetovana. O tome svjedoče i rezultati istraživanja provedeni u nekim europskim zemljama, poput Nizozemske i Češke Republike. Konkretno, Bernritter, van Ooijen i Müller (2017) ističu da će dodatni novčani iznos nizozemski potrošač ostaviti isključivo u onom slučaju kada je zadovoljan kvalitetom restoranske usluge. Nadalje, da je riječ o čimbeniku koji utječe i na to koliki će taj novčani iznos biti, svjedoče i rezultati istraživanja koje su proveli Kvasnička i Szalaiová (2015) te Kvasnička (2018). Ova istraživanja pokazuju da percepcija kvalitete pružene usluge utječe na visinu napojnice koju će češki potrošač ostaviti nakon pružene restoranske usluge. S druge strane, Azar (2004) ističe da će potrošači u SAD-u ostaviti napojnicu neovisno o kvaliteti upravo pružene restoranske usluge jer je ostavljanje ovog dodatnog novčanog iznosa za pruženu uslugu restorana ustaljena praksa, općeprihvaćena društvena norma i svojevrsni društveni imperativ kojim se nastoji postići da i ubuduće restoranska usluga bude iste ili čak i više razine kvalitete, pogotovo ako potrošač redovito objeduje u istom restoranu. Konačno, jedna od iznimno važnih dimenzija kvalitete restoranske usluge jest i kvaliteta hrane, a u tom su kontekstu El-Said i Shehata (2017) svojim istraživanjem potvrdili da je upravo kvaliteta obroka visoko ocijenjeno obilježje kvalitete usluge, koje će kao takvo pozitivno utjecati na spremnost gosta da restoranskom osoblju ostavi dodatni novčani iznos u vidu napojnice.

Pored kvalitete usluge, čimbenik promatranog potrošačkog ponašanja jest i kontakt poslužitelja s gostom (Whaley i O'Neill 2011). Štoviše, interakcija između korisnika i pružatelja usluge jedna je od dimenzija kvalitete usluge (Kvasnička 2018), a ta interakcija podrazumijeva i profesionalnost $i$ ljubaznost poslužitelja koje su upućene korisniku usluge. U tom kontekstu, Van Vaerenbergh i Holmqvist (2013: 1279) ističu kako „dobra usluga i napojnica predstavljaju uzrok i posljedicu odnosa razmjene između pružatelja usluge i posjetitelja restorana“, što upućuje na povezanost ovog čimbenika i sklonosti potrošača dobrovoljnom ostavljanju ovog dodatnog novčanog iznosa prilikom plaćanja usluge. Na povezanost ova dva čimbenika upućuju i Yesiltas i sur. (2014) te El-Said i Shehata (2017) na temelju rezultata svojih istraživanja. Nadalje, Becker i sur. (2012) naglašavaju da su upravo obilježja ponašanja poslužitelja jedan od osnovnih čimbenika koji je prisutan i opisivan u predmetnoj literaturi, i to u kontekstu istraživanja kako ova varijabla utječe na veličinu napojnice koju 
je potrošač sklon ostaviti za pruženu uslugu. Na to upućuje i Lynn (2006), prema kojemu ljubaznost osoblja može povećati iznos napojnice za najmanje 20 do $40 \%$.

Iako pojedini autori (npr. Seiter, Givens i Weger 2015) ističu da je gostima restorana bitno ponašanje poslužitelja, i dalje su u praksi prisutne situacije kada će gost ostaviti dodatni novčani iznos za pruženu uslugu, i to neovisno o kvaliteti usluge i ponašanju poslužitelja jer je to društvena norma, koja prema Lynnu (2006) određuje čak i koliki će konkretni dodatni novčani iznos za pruženu uslugu biti. Potrebno je istaknuti da o važnosti društvene norme kao čimbenika koji utječe na spremnost potrošača na ostavljanje dodatnog novčanog iznosa za pruženu uslugu u svojim radovima govore brojni autori, a ova je problematika promatrana u literaturi s društvenog, psihološkog, ekonomskog i marketinškog aspekta (Kowalczuk et al. 2019). Sa psihološkog aspekta, Azar (2009) ističe kako je ova društvena norma utemeljena u nastojanjima potrošača da izbjegnu neugodne osjećaje, a koji bi se mogli javiti zbog društvenog neodobravanja ako se ne ostavi napojnica za pruženu uslugu. Isto tako, motiv uključivanja potrošača u ovaj oblik ponašanja jest i njegova želja da izbjegne osjećaj krivnje, ali i da nagradi osoblje za kvalitetno pruženu uslugu (Azar 2020) ili pak kreira poželjnu društvenu sliku o sebi (Whaley i O'Neill 2011). Nadalje, ako se promatra ekonomski aspekt, Gössling i sur. (2021: 812) ističu da ,gdje je ostavljanje dodatnog novčanog iznosa za pruženu uslugu norma, značajne će biti i ekonomske implikacije“ ove aktivnosti. Doda li se tomu činjenica da ostavljanje napojnica ipak nije univerzalno prihvaćena društvena norma u svim zemljama (Were et al. 2021), onda ovo navedenu problematiku čini još interesantnijom za istraživanje.

Pođe li se od toga da gosti tijekom boravka u restoranu očekuju ne samo kvalitetnu uslugu nego i da će prilikom objedovanja u restoranu uživati u njegovo cjelokupnoj atmosferi (Jewell 2008), može se pretpostaviti da će biti spremniji na ostavljanje dodatnog novčanog iznosa za korištenu restoransku uslugu, a kako bi iskazali svoju zahvalnost za cjelokupno doživljeno iskustvo. Ova pretpostavka proizlazi iz spoznaje kako upravo elementi fizičkog okruženja prodajnog mjesta (u ovom slučaju restorana), poput osvjetljenja, mirisa, boja, dizajna prostora, čistoće, imaju ključnu ulogu u izazivanju više razine percipirane vrijednosti (osobito u slučaju uslužnog poduzeća), a koja zatim utječe na veću vjerojatnost određene reakcije potrošača, konkretno njegove sklonosti ostavljanja napojnice kao nagrade za kvalitetno pruženu uslugu i doživljeno iskustvo (Whaley, Kim i Kim 2019). Time se i fizička obilježja restorana, koja čine njegovu cjelokupnu atmosferu, također mogu smatrati čimbenicima koji će utjecati na sklonost potrošača da se uključi u ovo dobrovoljno plaćanje dodatnog novčanog iznosa za pruženu uslugu. Štoviše, Whaley, Kim i Kim (2019) ističu da i atmosfera restorana utječe ne samo na sklonost potrošača ostavljanju napojnice nego i na veličinu ovog iznosa.

Kada su u pitanju način plaćanja i visina napojnice, Saayman i Saayman (2015) ističu da, iako su u nekim zemljama dodatni novčani iznosi namijenjeni poslužiteljima usluge integralni dio računa za pruženu uslugu, u brojnim drugim zemljama ovo nije slučaj, odnosno korisnik usluge je taj koji odlučuje hoće li uopće izdvojiti dodatni novčani iznos za pruženu uslugu, i ako da, korisnik je taj koji može definirati veličinu tog iznosa. Pritom na potrošačevu odluku koliki će dodatni novčani iznos izdvojiti može utjecati i način plaćanja (gotovinsko ili kartično plaćanje). Istraživanja na koja u svojim radovima upućuju Saayman i Saayman (2015) te Lynn i sur. (1993) ukazuju na zaključak da je način plaćanja čimbenik koji utječe na visinu napojnice koju će potrošač u restoranu ostaviti poslužitelju za pruženu 
ugostiteljsku uslugu. Na temelju istraživanja provedenog na uzorku restoranskih gostiju u Hong Kongu, Dewald (2003) ukazuje na to da će oni potrošači koji se koriste gotovinskim načinom plaćanja u većem postotku ostaviti napojnicu u odnosu na potrošače koji se koriste kartičnim načinom plaćanja. Ipak, Lynn i sur. (1993: 480) upućuju na istraživanja koja su rezultirala zaključkom da potrošači koji se koriste kartičnim načinom plaćanja ostavljaju i veću napojnicu.

Konačno, na sklonost potrošača ostavljanju napojnice, kao i na visinu iznosa napojnice, može utjecati i raspoloženje posjetitelja restorana. Literatura upućuje na postojanje pozitivne veze između raspoloženja korisnika usluge i njegove spremnosti na ostavljanje napojnice, ali i veličine iznosa napojnice (npr. Becker et al. 2012; Kowalczuk et al. 2019). $\mathrm{Na}$ važnost raspoloženja gosta kao odrednice promatranog potrošačkog ponašanja upućuju i Lynn i McCall (2000).

\subsection{Mogućnost segmentacije tržišta s obzirom na sklonost potrošača ostavljanju dodatnog novčanog iznosa (napojnice) za pruženu uslugu}

Analiza dostupne literature upućuje na zaključak da su dosadašnja znanstvena istraživanja koja potvrđuju mogućnost grupiranja potrošača u zasebne segmente kada je ostavljanje napojnica u pitanju oskudna. Ipak, riječ je o istraživanjima (npr. Kowalczuk et al. 2019; Kruger i Saayman 2016) koja su potvrdila da se potrošači mogu grupirati u različite tržišne segmente, ovisno o tome koji motivacijski čimbenik dominantno utječe na njihovu sklonost ostavljanju napojnice. Istraživanje koje su proveli Kowalczuk i sur. (2019) pokazalo je da se mogu izdvojiti četiri grupe poljskih potrošača koje karakteriziraju različita demografska, društvena, ekonomska i bihevioralna obilježja kada je sklonost ostavljanju napojnica u pitanju. Nadalje, Kruger i Saayman (2016) utvrdili su postojanje triju tržišnih segmenata posjetitelja restorana u Južnoj Africi, a koji se, osim po dobi, razlikuju i prema njihovoj sklonosti ostavljanju napojnica u restoranima, te s obzirom na motive koji ih potiču na posjećivanje restorana.

Primjeri ovih istraživanja pokazuju da ne postoji univerzalan kriterij segmentacije potrošača kada je sklonost ostavljanju napojnice za primljenu restoransku uslugu u pitanju. Stoga ova tematika zavređuje daljnju pozornost znanstvenika kako bi se stekle dodatne znanstvene spoznaje i osiguralo bolje razumijevanje ovog oblika potrošačkog ponašanja pojedinca.

U nastavku rada, nakon opisa metodologije provedenog empirijskog istraživanja, opisuju se i diskutiraju rezultati koji se odnose na strukturu promatranih motivacijskih čimbenika i mogućnost segmentacije restoranskih gostiju s obzirom na njihovu sklonost ostavljanju napojnice, a koju karakteriziraju pojedini motivacijski čimbenici. 


\section{METODOLOGIJA ISTRAŽIVANJA}

\subsection{Opis mjernog instrumenta}

Prikupljanje primarnih podataka provedeno je anketnim istraživanjem, uz primjenu visoko strukturiranog anketnog upitnika kao mjernog instrumenta koji je ispitanicima bio dostupan u online obliku. Anketni se upitnik sastojao od triju dijelova.

Prvi dio anketnog upitnika činila su pitanja koja su imala za cilj utvrditi tko od ispitanika, koji su pristupili ispunjavanju upitnika, zaista može i nastaviti sudjelovati u istraživanju. Pitanja koja su u tom smislu bila postavljena glasila su: „Posjećujete li restorane?“ i „Jeste li ikada ostavili napojnicu u restoranu?“ Ako odgovor na bilo koje od navedenih pitanja nije bio potvrdan, ispitanike se zamolilo da dalje ne popunjavaju upitnik te su njihovi odgovori bili izuzeti iz analize podataka. Kada je ostavljanje dodatnog novčanog iznosa za pruženu uslugu u pitanju, brojni autori (npr. Lin 2020; Gössling et al. 2021; Lynn 2015; Chung i Heung 2007) ističu da je najčešće korišten kontekst istraživanja, kontekst ugostiteljskih usluga restorana. Slijedom navedenog, i za potrebe ovog istraživanja odabran je upravo navedeni kontekst.

Drugi dio anketnog upitnika sastojao se od tvrdnji kojima se mjerila sklonost potrošača ostavljanju dodatnog novčanog iznosa za pruženu ugostiteljsku uslugu u restoranima. Ovaj dio upitnika činilo je 38 tvrdnji koje su bile preuzete, i po potrebi prilagođene, iz dvaju znanstvenih istraživanja (Whaley, Lee i Kim 2019; Saayman i Saayman 2015) te su bile prevedene na hrvatski jezik. Tvrdnjama su se mjerile sljedeće varijable: (1) kvaliteta hrane i usluge, (2) ljubaznost i profesionalnost poslužitelja, (3) društvena norma, (4) obilježja restorana, (5) raspoloženje posjetitelja restorana te (6) način plaćanja i visina napojnice (izvori tvrdnji navedeni su u Tablici 2.). Ispitanike se bilo zamolilo da na postavljene tvrdnje odgovore tako da označe svoj stupanj slaganja s pojedinom tvrdnjom. U tom smislu, korištena je petostupanjska Likertova ljestvica, pri čemu je brojčana oznaka 1 označavala potpuno neslaganje ispitanika s postavljenom tvrdnjom, dok je brojčana oznaka 5 označavala potpuno slaganje ispitanika s tvrdnjom.

Na kraju anketnog upitnika postavljena su pitanja kojima su se prikupili opći podaci o ispitanicima (spol, dob, završen stupanj obrazovanja, trenutačni radni status i mjesečna primanja ispitanika). U nastavku slijedi opis uzorka.

\subsection{Opis uzorka}

U istraživanju je bio primijenjen namjerni, prigodni uzorak, a činilo ga je 106 ispitanika koji su na oba početna pitanja u upitniku dali potvrdan odgovor. Drugim riječima, u istraživanju su mogli sudjelovati samo oni ispitanici koji su izjavili da posjećuju restorane i da su barem jedanput u restoranu ostavili napojnicu za pruženu ugostiteljsku uslugu. Strukturu uzorka prikazuje Tablica 1. 
Tablica 1.: Struktura uzorka $(\mathrm{n}=106)$

\begin{tabular}{|c|c|c|}
\hline \multicolumn{2}{|l|}{ Obilježje ispitanika } & $\%$ \\
\hline \multirow{2}{*}{ Spol } & Muški & 26,4 \\
\hline & Ženski & 73,6 \\
\hline \multirow{6}{*}{ Dob } & $18-25$ & 50,9 \\
\hline & $26-35$ & 19,8 \\
\hline & $36-45$ & 8,5 \\
\hline & $46-55$ & 17,0 \\
\hline & $56-65$ & 2,8 \\
\hline & 66 i više & 0,9 \\
\hline \multirow{5}{*}{ Završen stupanj obrazovanja } & Osnovna škola & 1,9 \\
\hline & Srednja škola & 40,6 \\
\hline & Fakultet & 47,2 \\
\hline & Magisterij znanosti & 8,5 \\
\hline & Doktorat znanosti & 1,9 \\
\hline \multirow{5}{*}{ Trenutačni radni status } & Student/ica & 39,6 \\
\hline & Student/ica u radnom odnosu & 8,5 \\
\hline & Nezaposlen/a & 0,9 \\
\hline & Zaposlen/a & 46,2 \\
\hline & Umirovljenik/ica & 4,7 \\
\hline \multirow{7}{*}{ Mjesečna primanja ispitanika } & Do 2500 HRK & 27,4 \\
\hline & $2501-5000 \mathrm{HRK}$ & 17,0 \\
\hline & $5001-7500 \mathrm{HRK}$ & 21,7 \\
\hline & $7501-10000 \mathrm{HRK}$ & 10,4 \\
\hline & $10001-15000 \mathrm{HRK}$ & 7,5 \\
\hline & Više od 15000 HRK & 0,9 \\
\hline & Ne želim odgovoriti & 15,1 \\
\hline
\end{tabular}

Izvor: istraživanje

Iz navedene tablice vidljivo je da su uzorkom uglavnom bili obuhvaćeni mladi odrasli ispitanici u dobi od 18 do 35 godina $(70,7 \%)$. Većinu ispitanika obuhvaćenih uzorkom činile su ženske osobe $(73,6 \%)$. Većina ispitanika navodi kao završen stupanj formalnog obrazovanja srednju školu, odnosno fakultet $(87,8 \%)$. Nadalje, $85,8 \%$ ispitanika kao svoj trenutačni radni status navodi status studenta, odnosno da su u radnom odnosu. Kada se promotre mjesečna primanja pojedinca, može se uočiti da je većina ispitanika izjavila da raspolaže iznosom do 2.500,00 HRK (27,4 \%) ili od 5.001,00 do 7.500,00 HRK $(21,7 \%)$. 


\section{REZULTATI ISTRAŽIVANJA}

Prikupljeni primarni podaci analizirani su faktorskom analizom, izračunom Cronbachovih alfa koeficijenata te $k$-means klaster-analizom. U nastavku su prikazani postupci utvrđivanja psihometrijskih karakteristika mjernog instrumenta, kao i postupak utvrđivanja segmenata ispitanika koji se razlikuju s obzirom na sklonost ostavljanju dodatnog novčanog iznosa za pruženu ugostiteljsku uslugu u restoranu.

\subsection{Psihometrijske karakteristike mjernog instrumenta}

Analiza podataka započela je utvrđivanjem pouzdanosti i valjanosti mjernog instrumenta, odnosno utvrđivanjem psihometrijskih karakteristika korištenih mjernih ljestvica. To je učinjeno primjenom metode eksplorativne faktorske analize i izračunom Cronbachovih alfa koeficijenata. Eksplorativnom faktorskom analizom izdvojeno je šest faktora. Pritom je kao kriterij odabira broja faktora primijenjeno Kaiser-Guttmanovo pravilo: zadržavaju se oni faktori kojima je svojstvena vrijednost veća od 1. Kao metoda ekstrakcije faktora primijenjena je metoda glavnih komponenti, dok je kao metoda rotacije primijenjena varimax raw rotacija. Izdvojeni faktori objašnjavaju 69,9\% ukupne varijance. Dobivenu faktorsku strukturu prikazuje Tablica 2.

Tablica 2.: Rezultati faktorske analize $(\mathrm{n}=106)$

\begin{tabular}{|l|c|c|}
\hline Faktori i pripadajuće tvrdnje & $\begin{array}{c}\text { Faktorsko } \\
\text { opterećenje }\end{array}$ & $\begin{array}{c}\text { Cronbachov } \\
\text { alfa koeficijent }\end{array}$ \\
\hline $\begin{array}{l}\text { Faktor 1: Kvaliteta hrane i usluge } \\
\text { (izvor tvrdnji: Whaley, Lee } \text { i Kim 2019) }\end{array}$ & 0,85 \\
\hline $\begin{array}{l}\text { t_17: Ako je kvaliteta hrane u restoranu slaba, ostavit ću } \\
\text { manju napojnicu. }\end{array}$ & 0,69 & \\
\hline $\begin{array}{l}\text { t_18: Loša kvaliteta hrane u restoranu dovodi do toga da } \\
\text { uopće neću ostaviti napojnicu. }\end{array}$ & 0,64 & \\
\hline $\begin{array}{l}\text { t_21: Vrijeme čekanja na posluživanje hrane u restoranu } \\
\text { utječe na moju sklonost ostavljanju napojnice. }\end{array}$ & 0,66 & \\
\hline $\begin{array}{l}\text { t_22: Ako sam nezadovoljan/na uslugom koja mi je } \\
\text { pružena u restoranu, ostavit ću manju napojnicu. }\end{array}$ & 0,79 & \\
\hline $\begin{array}{l}\text { t_23: Moja sklonost ostavljanju napojnice u restoranu u } \\
\text { izravnoj je vezi s kvalitetom pružene usluge. }\end{array}$ & 0,79 & 0,86 \\
\hline $\begin{array}{l}\text { t_24: Ako nisam zadovoljan/na uslugom pruženom u } \\
\text { restoranu, neću ostaviti nikakvu napojnicu. }\end{array}$ & 0,74 & \\
\hline $\begin{array}{l}\text { Faktor 2: Ljubaznost i profesionalnost poslužitelja } \\
\text { (izvor tvrdnji: Saayman } i \text { Saayman 2015, prilagođeno })\end{array}$ & & \\
\hline $\begin{array}{l}\text { t_9: Ljubaznim konobarima/icama u restoranu imam } \\
\text { običaj ostaviti veću napojnicu. }\end{array}$ & 0,66 & \\
\hline $\begin{array}{l}\text { t_10: Konobarovo/ičino poznavanje ponude restorana } \\
\text { (jelovnika, vinske karte) utječe na moju sklonost } \\
\text { ostavljanju napojnice. }\end{array}$ & 0,82 & \\
\hline
\end{tabular}




\begin{tabular}{|l|c|c|}
\hline Faktori i pripadajuće tvrdnje & $\begin{array}{c}\text { Faktorsko } \\
\text { opterećenje }\end{array}$ & $\begin{array}{c}\text { Cronbachov } \\
\text { alfa koeficijent }\end{array}$ \\
\hline $\begin{array}{l}\text { t_11: Što konobar/ica bolje poznaje ponudu restorana } \\
\text { (jelovnik, vinsku kartu), veća je napojnica koju ću mu/joj } \\
\text { ostaviti. }\end{array}$ & 0,83 & \\
\hline $\begin{array}{l}\text { t_12: Profesionalnost konobara/ica najviše utječe na moju } \\
\text { sklonost ostavljanju napojnice u restoranu. }\end{array}$ & 0,74 & \\
\hline $\begin{array}{l}\text { t_13: Ako je konobar/ica u restoranu prijateljski } \\
\text { nastrojen/a, ostavit ću mu/joj veću napojnicu. }\end{array}$ & 0,84 & \\
\hline $\begin{array}{l}\text { Faktor 3: Društvena norma } \\
\text { (izvor tvrdnji: Whaley, Lee } i \text { Kim 2019, prilagođeno) }\end{array}$ & & 0,74 \\
\hline $\begin{array}{l}\text { t_1: U restoranu ponekad osjećam pritisak da moram } \\
\text { ostaviti napojnicu. }\end{array}$ & 0,66 & \\
\hline $\begin{array}{l}\text { t_2: Osjećam veću obvezu ostaviti napojnicu kada sam u } \\
\text { restoranu s obitelji. }\end{array}$ & 0,86 & \\
\hline $\begin{array}{l}\text { t_3: Osjećam veću obvezu ostaviti napojnicu kada sam u } \\
\text { restoranu s prijateljima. }\end{array}$ & 0,87 & \\
\hline $\begin{array}{l}\text { Faktor 4: Obilježja restorana } \\
\text { (izvor tvrdnji: Saayman } i \text { Saayman 2015, prilagođeno) }\end{array}$ & & 0,72 \\
\hline $\begin{array}{l}\text { t_35: Vrsta restorana koji posjećujem utječe na moju } \\
\text { sklonost ostavljanju napojnice. }\end{array}$ & 0,72 & \\
\hline $\begin{array}{l}\text { t_36: Umirujuća pozadinska glazba u restoranu utječe na } \\
\text { moju sklonost ostavljanju veće napojnice. }\end{array}$ & 0,76 & \\
\hline $\begin{array}{l}\text { t_37: Veća je vjerojatnost da ću ostaviti veću napojnicu } \\
\text { ako je restoran na atraktivnoj lokaciji. }\end{array}$ & 0,68 & \\
\hline $\begin{array}{l}\text { Faktor 5: Način plaćanja i visina napojnice } \\
\text { (izvor tvrdnji: Saayman } i \text { Saayman 2015, prilagođeno) }\end{array}$ & & \\
\hline $\begin{array}{l}\text { t_26: Kada u restoranu plaćam gotovinom, ostavljam } \\
\text { manju napojnicu nego inače. }\end{array}$ & 0,79 & \\
\hline $\begin{array}{l}\text { t_27: Kada u restoranu plaćam karticom, ostavljam veću } \\
\text { napojnicu nego inače. }\end{array}$ & 0,84 & \\
\hline $\begin{array}{l}\text { Faktor 6: Raspoloženje posjetitelja restorana } \\
\text { (izvor tvrdnji: Saayman } i \text { Saayman 2015, prilagođeno) }\end{array}$ & & \\
\hline $\begin{array}{l}\text { t_30: Moje raspoloženje tijekom boravka u restoranu } \\
\text { uvelike utječe na moju sklonost ostavljanju napojnice. }\end{array}$ & 0,84 & \\
\hline $\begin{array}{l}\text { t_31: Što sam u restoranu raspoloženiji/ija, ostavit ću } \\
\text { veću napojnicu za pruženu uslugu. }\end{array}$ & 0,81 & \\
\hline
\end{tabular}

Izvor: istraživanje

U istraživanju je bilo primijenjeno ukupno 38 tvrdnji, no s obzirom na to da je 21 tvrdnju karakteriziralo visoko faktorsko opterećenje na pripadajućem faktoru i niska faktorska opterećenja na ostalim faktorima, daljnja se analiza podataka temeljila na toj 21 tvrdnji. Tvrdnje su činile sljedećih šest faktora: kvaliteta hrane i usluge, ljubaznost i profesional- 
nost poslužitelja, društvena norma, obilježja restorana, način plaćanja i visina napojnice te raspoloženje posjetitelja restorana. Nadalje, izračunom Cronbachovih alfa koeficijenata utvrđena je pouzdanost primijenjenih mjernih ljestvica. Raspon Cronbachovih alfa koeficijenata u slučaju promatranih mjernih ljestvica kreće se između 0,67 i 0,86 , a to dovodi do zaključka da postoji prihvatljiva razina pouzdanosti mjernih ljestvica koje su primijenjene u istraživanju (Kline 1998).

\subsection{Segmenti potrošača s obzirom na njihovu sklonost ostavljanju dodatnog novčanog iznosa za primljenu ugostiteljsku uslugu u restoranima}

Kako bi se utvrdilo postoje li segmenti potrošača koji se razlikuju u svojemu ponašanju kada je u pitanju ostavljanje dodatnog novčanog iznosa (napojnice) za pruženu ugostiteljsku uslugu u restoranima, provedena je $k$-means klaster-analiza. Rezultat ove analize bile su tri grupe ispitanika, koje su nazvane kako slijedi: Kvaliteti usluge orijentirani (segment 1), Društvenoj normi orijentirani (segment 2) i Ad hoc segment (segment 3).

Nadalje, analiza varijance pokazala je postojanje statistički značajnih razlika između srednjih vrijednosti koje se odnose na ove tri izdvojene grupe. Tablica 3. prikazuje rezultate $k$-means klaster-analize.

Tablica 3.: Rezultati klaster-analize, srednje vrijednosti $(\mathrm{n}=106)$

\begin{tabular}{|l|c|c|c|c|}
\hline FAKTOR & $\begin{array}{c}\text { Segment 1 } \\
\text { Kvaliteti } \\
\text { usluge } \\
\text { orijentirani } \\
(n=29)\end{array}$ & $\begin{array}{c}\text { Segment 2 } \\
\text { Društvenoj } \\
\text { normi } \\
\text { orijentirani } \\
(n=35)\end{array}$ & $\begin{array}{c}\text { Segment 3 } \\
\text { Ad } \\
\text { hoc } \\
\text { segment } \\
(n=42)\end{array}$ & ANOVA \\
\hline F1: Kvaliteta hrane i usluge & 4,38 & 3,64 & 3,42 & $\begin{array}{c}\mathrm{F}=12,77 \\
\mathrm{p}=0,00\end{array}$ \\
\hline $\begin{array}{l}\text { F2: Ljubaznost i } \\
\text { profesionalnost poslužitelja }\end{array}$ & 4,43 & 3,78 & 3,66 & $\begin{array}{c}\mathrm{F}=9,89 \\
\mathrm{p}=0,00\end{array}$ \\
\hline F3: Društvena norma & 2,52 & 3,37 & 1,60 & $\begin{array}{c}\mathrm{F}=67,13 \\
\mathrm{p}=0,00\end{array}$ \\
\hline F4: Obilježja restorana & 3,39 & 2,37 & 1,94 & $\begin{array}{c}\mathrm{F}=31,72 \\
\mathrm{p}=0,00\end{array}$ \\
\hline $\begin{array}{l}\text { F5: Način plaćanja i visina } \\
\text { napojnice }\end{array}$ & 2,38 & 1,53 & 1,75 & $\begin{array}{c}\mathrm{F}=10,28 \\
\mathrm{p}=0,00\end{array}$ \\
\hline $\begin{array}{l}\text { F6: Raspoloženje posjetitelja } \\
\text { restorana }\end{array}$ & 4,43 & 3,06 & 2,83 & $\begin{array}{c}\mathrm{F}=31,52 \\
\mathrm{p}=0,00\end{array}$ \\
\hline
\end{tabular}

Izvor: istraživanje

Kvaliteti usluge orijentirani naziv je prvog segmenta potrošača koji za primljenu uslugu u restoranima ostavljaju napojnicu. Za ovaj segment posjetitelja restorana karakteristično je to da ljubaznost i profesionalnost poslužitelja, kao i njihovo raspoloženje kao gosta 
tijekom boravka u restoranu, najviše utječe na njihovu sklonost ostavljanju napojnice za primljenu uslugu. Isto tako, ovo je segment na čiju će sklonost ostavljanju dodatnog novčanog iznosa za pruženu uslugu u najvećoj mjeri utjecati njihova percepcija kvalitete hrane i primljene restoranske usluge.

Drugi segment potrošača nazvan je Društvenoj normi orijentirani. Promatrajući sva tri izdvojena segmenta, ovdje je riječ o posjetiteljima restorana na čije će ponašanje najviše utjecati društvena norma kada je ostavljanje napojnice u pitanju. Ujedno, ovaj segment potrošača u najmanjoj mjeri karakterizira način plaćanja kao odrednice visine iznosa napojnice.

Treći segment potrošača nazvan je Ad hoc segmentom. S jedne strane, sličan je drugom segmentu, ali se od njega značajno razlikuje u kontekstu čimbenika ,društvena norma“. S druge strane, ako se promatraju obilježja ovog segmenta u odnosu na prethodna dva, onda je u pitanju segment kod kojega su najmanje izraženi čimbenici, i to već spomenuta društvena norma, ali i obilježja restorana te raspoloženje posjetitelja restorana.

\section{RASPRAVA}

Za prvi segment potrošača, nazvan Kvaliteti usluge orijentirani, karakteristično je to da je u pitanju segment koji je obilježen većim brojem motivacijskih čimbenika od preostalih dvaju izdvojenih segmenata. Uz sklonost ovog segmenta potrošača da ostavi napojnicu u najvećoj se mjeri vežu ljubaznost i profesionalnost poslužitelja, njihovo raspoloženje kao gostiju izazvano boravkom u restoranu, te kvaliteta hrane i općenito pružene usluge. Ovo su potrošači koji, u odnosu na druga dva segmenta, najviše cijene profesionalan i stručan te prijateljski i srdačan pristup restoranskog osoblja usmjeren njima kao gostima, a to cee ih potaknuti na ostavljanje napojnice, ali će utjecati i na visinu tog dodatnog novčanog iznosa koji će izdvojiti uz plaćanje usluge. Na sklonost ostavljanju napojnice, kao i na visinu napojnice, također će utjecati i njihovo raspoloženje tijekom boravka u restoranu, za koje se može pretpostaviti da je u pozitivnoj vezi s profesionalnim i ljubaznim odnosom restoranskog osoblja i njih kao gostiju restorana. Konačno, ovo je i segment potrošača koji će, u odnosu na druga dva segmenta, više pozornosti obraćati na kvalitetu hrane i općenito usluge koja je pružena, a to će pak utjecati na njihovu odluku hoće li uopće ostaviti napojnicu za pruženu uslugu i koliki će taj iznos biti.

Prethodno opisani segment potrošača ima određenih dodirnih točaka sa segmentima potrošača koje su u svojim istraživanjima izdvojili Kowalczuk i sur. (2019) te Kruger i Saayman (2016), premda navedena istraživanja nisu testirala identične motivacijske čimbenike ostavljanja napojnice za pruženu uslugu. Ipak, određena se sličnost ovog segmenta sa segmentima potvrđenim u okviru navedenih inozemnih istraživanja može prepoznati. Tako na primjer, u istraživanju koje su proveli Kowalczuk i sur. (2019), segment potrošača zadovoljnih ponudom karakterizira također motivacijski čimbenik koji se odnosi na ponudu restorana, koja se može smatrati dijelom kvalitete usluge, a koja je također jedan od motivacijskih čimbenika ostavljanja napojnice u slučaju segmenta Kvaliteti usluge orijentiranih potrošača. Nadalje, segment Kvaliteti usluge orijentiranih potrošača, kao i segment koji su u svojemu istraživanju izdvojili Kruger i Saayman (2016), a koje navedeni autori opisuju kao hedoniste, također pokazuju određenu sličnost jer je i ponašanje segmenta hedonistič- 
kih potrošača okarakterizirano prije svega njihovim raspoloženjem tijekom boravka u restoranu, što je važan motivacijski čimbenik ostavljanja napojnice i kada su Kvaliteti usluge orijentirani potrošači u pitanju.

Društvenoj normi orijentirani predstavlja drugi segment potrošača koji je izdvojen na temelju rezultata ovog istraživanja. U odnosu na ostala dva segmenta, ovo su potrošači kod kojih je sklonost ostavljanju napojnice najviše pod utjecajem njihove percepcije društvenih očekivanja, odnosno društvenog pritiska da se ostavi napojnica za primljenu restoransku uslugu. Ovo je ujedno i segment kod kojega će u najmanjoj mjeri biti izražena veza između načina plaćanja i visine napojnice. Drugim riječima, bez obzira na to plaća li se pružena usluga gotovinski ili kartično, to neće imati utjecaja na odluku ovih potrošača o visini iznosa napojnice. Na temelju svega navedenog, moglo bi se pretpostaviti da ovi potrošači slijede ne samo percipirani društveni imperativ ostavljanja napojnice nego i da taj iznos napojnice čini neki uobičajeni ili općeprihvaćeni iznos ili pak postotak od ukupne cijene usluge.

Konačno, treći segment, nazvan Ad hoc segment, čine oni potrošači kod kojih su najmanje izraženi čimbenici društvena norma, obilježja restorana i raspoloženje gosta tijekom boravka u restoranskom okruženju, iz čega se može pretpostaviti da su u pitanju potrošači kod kojih nije jasno definiran motivacijski čimbenik ostavljanja napojnice. Drugim riječima, rezultati istraživanja koji se odnose na ovaj segment potrošača, upućuju na pretpostavku da ovi potrošači nemaju jasno definiran stav prema ostavljanju napojnice za primljenu restoransku uslugu te da je ovaj oblik njihova potrošačkog ponašanja situacijski uvjetovan nekim trenutačnim čimbenikom koji će ih prilikom plaćanja korištene usluge potaknuti na davanje dodatnog novčanog iznosa u vidu napojnice.

Treba ujedno istaknuti i to da se prethodna dva segmenta (Društvenoj normi orijentirani $i$ Ad hoc segment) razlikuju od segmenata izdvojenih u analiziranim inozemnim istraživanjima, što navodi na pretpostavku da su ne samo općenita sklonost ostavljanju napojnice za pruženu uslugu nego i motivacijski čimbenici ostavljanja napojnice kulturološki uvjetovani, što otvara prostor daljnjim istraživanjima ove problematike.

\section{ZAKLJUČAK}

Provedeno istraživanje pridonosi boljem razumijevanju ponašanja potrošača i motivacijskih čimbenika koji karakteriziraju njihovu sklonost da prilikom korištenja restoranskih usluga, pored plaćene cijene usluge, ostave i dodatni novčani iznos (napojnicu). Istraživanje je pokazalo da se potrošači mogu podijeliti u različite segmente, a razlike među njima postoje s obzirom na to koji ih čimbenici motiviraju na ostavljanje napojnice u restoranskom okruženju.

Rezultati provedenog anketnog istraživanja pokazali su da postoje različite strukture motivacijskih čimbenika kada je u pitanju ostavljanje napojnica za pruženu restoransku uslugu, kao i to da se na temelju tih razlika potrošači mogu grupirati u tri zasebna tržišna segmenta, ovisno o tome koja kombinacija motivacijskih čimbenika karakterizira promatrani oblik potrošačkog ponašanja. Ovo se ujedno može smatrati i osnovnim teorijskim doprinosom rada. Praktičan doprinos rada ogleda se u tome što se marketinškim stručnjacima u području restoranskih usluga pružaju smjernice koje dimenzije restoranske usluge poboljšati, a što će potencijalno povećati zadovoljstvo posjetitelja te ih ohrabriti na ostavljanje 
napojnice. Ostavljanje napojnice za pruženu uslugu na taj način zasigurno može utjecati i na veće zadovoljstvo zaposlenika, a koje je u slučaju uslužnih poduzeća od posebnog značaja jer se ono može odraziti na percepciju kvalitete usluge. Osim toga, spoznaje o postojanju različitih tržišnih segmenata s obzirom na motivacijske čimbenike koji karakteriziraju njihovu sklonost ostavljanju napojnice mogu pomoći marketinškim stručnjacima i u ciljanom odabiru motivacijskog čimbenika koji će poslužiti kao učinkovit komunikacijski argument privlačenja pozornosti i ohrabrivanja potrošača na posjet restoranu, a to bi u konačnici moglo dovesti i do odluke potrošača o ostavljanju napojnice za primljenu uslugu.

Prilikom interpretacije rezultata provedenog istraživanja potrebno je u obzir uzeti i njegova ograničenja. Kao i u slučaju nekih dosadašnjih istraživanja ove tematike (npr. Becker et al. 2012), tako je i ovo istraživanje bilo izviđajne naravi, stoga je u njegovoj provedbi primijenjen namjerni, prigodni uzorak. S obzirom na to da odabir namjernog uzorka ispitanika za sobom povlači činjenicu da „,rezultati vrijede samo za uzorak na kojemu su prikupljeni“ (Vranešević 2014: 362), prilikom tumačenja nalaza ovog istraživanja treba uzeti u obzir da su dobiveni rezultati prije svega indikativni te bi u svrhu njihove generalizacije trebalo provesti istraživanje na reprezentativnom uzorku. S druge, pak, strane, rezultati istraživanja dobiveni primjenom namjernog, prigodnog uzorka ipak mogu pomoći u postavljanju istraživačkih hipoteza u budućim istraživanjima (Fricker i Shonlau 2002), a kojima će se nastojati iscrpnije istražiti različiti motivacijski (i ostali) čimbenici i njihov utjecaj na promatrano ponašanje potrošača.

Vezano uz daljnja ograničenja koja se odnose na vrstu primijenjenog uzorka, treba istaknuti i sljedeće. Unatoč tome što su u istraživanju mogli sudjelovati isključivo ispitanici koji su potvrdno odgovorili na oba početna pitanja postavljena u upitniku („Posjećujete li restorane?" i ,Jeste li ikad ostavili dodatni novčani iznos u restoranu?"), provedeno istraživanje ipak se temelji na podacima koji su prikupljeni na uzorku ograničene veličine i koji su činili pretežito mladi odrasli potrošači te su uzorkom u većoj mjeri bile obuhvaćene ženske osobe. Stoga se vrsta i veličina uzorka mogu smatrati prvim ograničenjem provedenog istraživanja. Buduća istraživanja trebala bi uzeti u obzir ovo metodološko ograničenje istraživanja te bi se trebala temeljiti na reprezentativnom, slučajnom uzorku ispitanika.

Nadalje, u ovom su istraživanju sudjelovali samo oni ispitanici koji u restoranima ostavljaju napojnicu. Preporuka je da se u budućim istraživanjima uzorkom obuhvati i one ispitanike koji ne ostavljaju napojnicu te istraži razloge njihova neuključivanja u promatrani oblik potrošačkog ponašanja, kao i ostale čimbenike koji dovode do takve odluke. S tim u vezi, u budućim istraživanjima bilo bi korisno istražiti i iznos napojnice koji potrošači uobičajeno ostavljaju za pruženu uslugu u restoranima, a kako bi se saznala prosječna vrijednost ovog dodatnog novčanog troška kojemu se potrošači svojevoljno odluče izložiti ili ne izložiti.

Kao sljedeće ograničenje istraživanja može se navesti i njegov kontekst, a to su usluge restorana. Iako je većina istraživanja o ovom obliku potrošačkog ponašanja provedena upravo u kontekstu restorana (Yoo, Lee i Bai 2011; Chang i Chiu 2008), ponašanje potrošača u vidu ostavljanja napojnice može se razlikovati i ovisno o tome koja je vrsta usluge u pitanju (Koku 2005). Stoga bi buduća istraživanja mogla biti provedena i u kontekstu drugih usluga (npr. usluge prijevoza taksijem, usluge frizerskih salona, usluge dostave proizvoda putem mobilnih aplikacija).

Nadalje, osim što se promatrano ponašanje potrošača može razlikovati ovisno o vrsti usluge koja se pruža, ono se može razlikovati i ovisno od zemlje do zemlje (Gössling et 
al. 2021), a ta činjenica dovodi do preporuke da se ovakva istraživanja provedu i u drugim kulturno-društvenim okruženjima, a posebice u europskim zemljama, gdje se, kako to navode Gössling i sur. (2021: 818), ,uzorci ponašanja u smislu ostavljanja dodatnog novčanog iznosa za pruženu uslugu čine znatno različitijima i složenijima od onih prikazanih u provedenim istraživanjima u Sjevernoj Americi“.

Kao što je iz prethodnog vidljivo, navedena ograničenja istraživanja mogu se shvatiti i kao preporuke za buduća istraživanja ove tematike. Za potrebe ovog rada bio je odabran najčešće korišten kontekst istraživanja kada je ostavljanje dodatnog novčanog iznosa za pruženu uslugu u pitanju, a to su ugostiteljske usluge restorana. Jedno od obrazloženja zašto je upravo ovaj sektor najčešće istraživan kada je u pitanju promatrano potrošačko ponašanje može biti to da je riječ o sektoru usluga koji čini neizostavan i važan dio turističke ponude neke zemlje kao turističke destinacije (Saayman i Saayman 2015). Stoga bi u budućim istraživanjima bilo interesantno utvrditi i postoji li razlika u ponašanju domaćih i inozemnih turista u njihovoj sklonosti ostavljanju dodatnog novčanog iznosa za pruženu uslugu, tim više što je promatrano ponašanje potrošača kulturološki uvjetovano, kao što je kulturološki uvjetovana i sama praksa, odnosno očekivanje ili pak neprihvatljivost ostavljanja dodatnog novčanog iznosa za pruženu uslugu na razini pojedine zemlje kao receptivne turističke destinacije.

Konačno, razumijevanje zašto su potrošači spremni ostaviti dodatni novčani iznos za pruženu uslugu predstavlja interesantno područje izučavanja upravo zbog toga što se potrošači dobrovoljno, namjerno i svjesno odlučuju na ovakvo, naizgled iracionalno ekonomsko ponašanje u vidu izlaganja višoj razini ukupnog novčanog troška. Može se zaključiti da se takvo ponašanje temelji i na nekima od najvažnijih determinanti njihova kupovnog ponašanja, a to su percepcija i motivacijski čimbenici - u ovom slučaju, percepcija cjelokupne kupovne situacije i društvenih očekivanja, koja ujedno određuje i kakav će u konačnici biti promatrani oblik ponašanja potrošača, odnosno kolika će biti sklonost ostavljanju napojnice za primljenu uslugu te koji će čimbenici prvenstveno motivirati potrošača da se u takav oblik ponašanja uključi.

\section{LITERATURA}

1. Azar, O. H. (2004). What sustains social norms and how they evolve? The case of tipping. Journal of Economic Behavior \& Organization, 54, str. 49-64.

2. Azar, O. H. (2009). Tipping motivations and behavior in the US and Israel. MPRA Paper No. 20304. https://mpra.ub.uni-muenchen.de/20304/ (datum pristupanja: 28. 11. 2021.).

3. Azar, O. H. (2020). The Economics of Tipping. Journal of Economic Perspectives, 34(2), str. 215-236.

4. Becker, C., Bradley, G. T., Zantow, K. (2012). The underlying dimensions of tipping behavior: An exploration, confirmation, and predictive model. International Journal of Hospitality Management, 31(1), str. 247-256.

5. Bernritter, S. F., van Ooijen, I., Müller, B. C. N. (2017). Self-persuasion as marketing technique: the role of consumers' involvement. European Journal of Marketing, 51(5/6), str. 1075-1090. DOI 10.1108/EJM-04-2015-0213 
6. Casey, B. (2001a). Tipping in New Zealand restaurants. International Journal of Hospitality Management, 20(2), str. 219-225.

7. Casey, B. (2001b). Tipping in New Zealand's Restaurants. Cornell Hotel and Restaurant Administration Quarterly, 42(1), str. 21-25.

8. Chang, J. C., Chiu, C.-P. (2008). Perceptions of package tour providers about tipping in Taiwan. Tourism, 56(4), str. 355-370.

9. Chung, M. K. H., Heung, V. C. S. (2007). Tipping Behavior of Diners in Three Upscale Chinese Restaurants in Hong Kong. Asia Pacific Journal of Tourism Research, 12(3), str. 169-180. DOI: 10.1080/10941660701416739

10. Dewald, B. (2003). Tipping in Hong Kong restaurants. International Journal of Hospitality Management, 22(3), str. 307-319.

11. El-Said, O. A., Shehata, H. S. (2017). Tipping Motives in Egyptian Restaurants: Customers' View. Journal of Tourism Research, 16, str. 172-194.

12. Fisher, D. (2009). Grid-group analysis and tourism: tipping as a cultural behavior. Journal of Tourism and Cultural Change, 7(1), str. 34-47. https://doi. org/10.1080/14766820902807672

13. Fricker, R. D., Shonlau, M. (2002). Advantages and Disadvantages of Internet Research Surveys: Evidence from the Literature. Field Methods, 14(4), str. 347-367. https:// doi.org/10.1177/152582202237725

14. Gössling, S., Fernandez, S., Martin-Rios, C., Pasamar Reyes, S., Fointiat, V., Isaac, R. K., Lunde, M. (2021). Restaurant tipping in Europe: a comparative assessment. Current Issues in Tourism, 24(6), str. 811-823. https://doi.org/10.1080/13683500.2020. 1749244

15. Hoaas, D. J., Bigler, L. (2005). The Relationship Between Tipping and Service Quality: The Other Side of the Equation. Southwestern Economic Review Proceedings, str. 17-26.

16. Jewell, C. N. (2008). Factors Influencing Tipping Behavior in a Restaurant. Psi Chi Journal of Undergraduate Research, 13(1), str. 38-48. DOI: 10.24839/1089-4136. JN13.1.38

17. Kline, R. B. (1998). Principles and Practice of Structural Equation Modeling. The Guilford Press, New York, NY.

18. Koku, P. S. (2005). Is there a difference in tipping in restaurant versus non-restaurant service encounters, and do ethnicity and gender matter? Journal of Services Marketing, 19(6/7), str. 445-452. DOI:10.1108/08876040510625954

19. Kowalczuk, I., Gębski, J., Maciąg, A., Sawicka, B. (2019). Tipping Behavior of Polish Consumers - The Segmentation Approach. Economic Problems of Tourism, 1, str. 53-61. DOI: 10.18276/ept.2019.1.45-05

20. Kruger, M., Saayman, M. (2016). The dining and tipping behaviour of Black South Africans: a segmentation approach. Southern African Business Review, 20, str. 336364.

21. Kvasnička, M. (2018). What Motivates Restaurant Customers to Tip: Evidence From the Czech Republic. Acta Universitatis Agriculturae et Silviculturae Mendelianae Brunensis, 66(1), str. 273-282. https://doi.org/10.11118/actaun201866010273 
22. Kvasnička, M., Szalaiová, M. (2015). Determinants of Gratuity Size in the Czech Republic: Evidence from Four Inexpensive Restaurants in Brno. Review of Economic Perspectives - Národohospodářský Obzor, 15(2), str. 3-17. DOI: 10.1515/revecp-2015-0013

23. Lin, T.-C. (2020). Restaurant Tipping and Economic Efficiency in the Restaurant Market: An Economic Theoretical Analysis, Theoretical Economics Letters, 10, str. 1136-1145.

24. Liu, C.-M. (2008). The perceptions of waiters and customers on restaurant tipping. Journal of Services Marketing, 22(2), str. 95-103. DOI 10.1108/08876040810862840

25. Lynn, M. (2006). Tipping in restaurants and around the globe: An interdisciplinary review, Cornell University, School of Hospitality Administration, http://scholarship. sha.cornell.edu/articles/99 (datum pristupanja: 20. 3. 2021.).

26. Lynn, M. (2015). Explanations of Service Gratuities and Tipping: Evidence from Individual Differences in Tipping Motivations and Tendencies. Journal of Behavioral and Experimental Economics, 55, str. 65-71.

27. Lynn, M., McCall, M. (2000). Gratitude and gratuity: A meta-analysis of research on the service-tipping relationship. Dostupno na: http://scholarship.sha.cornell.edu/ articles/152 (datum pristupanja: 19. 10. 2021.).

28. Lynn, M., Zinkhan, G. M., Harris, J. (1993). Consumer Tipping: A Cross-Country Study. Journal of Consumer Research, 20(3), str. 478-488.

29. Parrett, M. (2006). An Analysis of the Determinants of Tipping Behavior: A Laboratory Experiment and Evidence from Restaurant Tipping. Southern Economic Journal, 73(2), str. 489-514.

30. Raspor, A., Divjak, M. (2017). What is tipping in post-communist countries? A Case study from Slovenia. Teorija in praksa, 54(6), str. 1023-1039.

31. Saayman, M., Saayman, A. (2015). Understanding tipping behaviour - an economic perspective. Tourism Economics, 21(2), str. 247-265.

32. Seiter, J. S., Givens, K. D., Weger Jr., H. (2015). The Effect of Mutual Introductions and Addressing Customers by Name on Tipping Behavior in Restaurants, Journal of Hospitality Marketing \& Management, 25(5), str. 640-651. DOI: 10.1080/19368623.2015.1040140

33. Van Vaerenbergh, Y., Holmqvist, J. (2013). Speak my language if you want my money. Service language's influence on consumer tipping behavior. European Journal of Marketing, 47(8), str. 1276-1292. DOI 10.1108/03090561311324327

34. Vranešević, T. (2014). Tržišna istraživanja u poslovnom upravljanju, Accent, Zagreb.

35. Were, S., Miricho, M., Maranga, V. (2021). Restaurant tipping behavior and its inspiration on food service empathy: a focus on two- and three-star hotels in Kenya, International Hospitality Review, 35(1), str. 57-69. DOI 10.1108/IHR-07-2020-0026

36. Whaley, J. E., Kim, S.-H., Kim, Y.-K. (2019). Drivers and impact of restaurant tipping behavior. Journal of Foodservice Business Research, 22(2), str. 117-131. DOI: 10.1080/15378020.2019.1570773

37. Whaley, J., Lee, J., Kim, Y. (2019). Do tipping motivations predict loyalty to the server in a restaurant?. International Hospitality Review, 33(2), str. 91-105. 
38. Whaley, J. E., O'Neill, M. (2011). To tip or not to tip? An exploratory study of the motivations driving consumer tipping behavior. Proceedings of the Sixteenth Annual Graduate Education and Graduate Student Research Conference in Hospitality and Tourism (Pilot-II), https://scholarworks.umass.edu/cgi/viewcontent.cgi?article $=1142 \&$ context=gradconf_hospitality (datum pristupanja: 16. 10. 2021.)

39. Yesiltas, M., Zorlu, O., Sop, S. A., Beydilli, E. T. (2014). The Effects of Service Quality on Customers' Tipping Behavior. International Journal of Academic Research in Business and Social Sciences, 4(8), str. 430-446.

40. Yoo, M., Lee, S., Bai, B. (2011). Hospitality marketing research from 2000 to 2009: Topics, methods, and trends. International Journal of Contemporary Hospitality Management, 23(4), str. 517-532. DOI 10.1108/09596111111130010 